\title{
A gombatermesztés szerepe az átalakuló magyar mezőgazdaságban
}

\author{
Horváth Gábor \\ Veszprémi Egyetem Georgikon Mezőgazdaságtudományi Kar, \\ Keszthely
}

\section{ÖSSZEFOGLALASS}

A közeledö Európai Uniós csatlakozás előtt (és azzal együtt) a magyar agrárgazdaságnak várhatóan jelentős változásokon kell átmennie. A termelési szerkezetnek alkalmazkodnia kell az Európai Unió követelményeihez és mindezek mellett meg kellene öriznie a magyar mezögazdaság világpiaci versenyképességét is. Az új szerkezetben nagyobb figyelmet kellene forditani a komparativ elönyeinket jól kihasználó, jó piaci lehetöségekkel bíró speciális termékekre (aprócikkekre) is. Az ide tartozó termékek a kistermelés keretei között is gazdaságosan állithatók elö, kereskedelmük korlátozásokkal nem vagy csak kevésbé sújtott, piacuk pedig sok esetben szinte korlátlan. A cikk egy ilyen speciális termékkel, a gombával foglalkozik. A gombatermesztés az elmúlt évtizedben hazánkban jelentös fejlödésnek indult, a termelés négyszeresére, az export pedig ötszörösére növekedett. Amennyiben sikerül továbbra is a megfelelö hátteret biztositani (szaktanácsadás, kedvezményes kölcsönök stb.), akkor a gombatermesztés a jövöben a magyar mezögazdaság egyik legjövedelmezöbb ágazata lehet.

\section{SUMMARY}

The structure of Hungarian agriculture should be changed before the EU accession. The new structure should fulfill EU requirements and also produce competitive products. Unconventional products (mushroom, fish, honey etc.) have a lot of advantages: they can be produced on small farms, their trade is mainly free of regulation and their markets are almost unlimited. This paper deals with one of these alternative agricultural enterprises, namely mushroom production. Hungarian mushroom production - in spite of difficulties - has witnessed remarkable expansion: it has increased its production by fourfold and its export by fivefold in less than ten years. The low level of wages gives Hungary significant advantage over its competitors. If we could ensure the appropriate infrastructure (technical advice, bank loans, etc.) the mushroom industry would become one of the most profitable sectors of Hungarian agriculture.

A közeledő Európai Uniós csatlakozás előtt (és azzal együtt) a magyar agrárgazdaságnak - s így természetesen az agrár-külkereskedelemnek is várhatóan jelentős változásokon kell átmennie. A termelési- és exportszerkezetnek alkalmazkodnia kell az Európai Unió követelményeihez és mindezek mellett meg kellene öriznie a magyar agrártermékek világpiaci versenyképességét is.

Jelenlegi agrárexportunk a támogatási versenynek leginkább kitett, jelentős kereskedelmi korlátokkal sújtott termékkörökben (pl. búza, sertéshús stb.) kínál nagyobb mennyiségeket. Ezek a termékek előreláthatólag a jövőben is fontos szerepet fognak játszani az agrárexportunkban, azonban mellettük nagyobb figyelmet kellene fordítani a komparatív előnyeinket jól kihasználó, jó piaci lehetőségekkel bíró speciális termékekre is. Az ide tartozó termékek a kistermelés keretei között is gazdaságosan állíthatók elö, kereskedelmük korlátozásokkal nem vagy csak kevésbé sújtott, piacuk pedig sok esetben szinte korlátlan. Az agrárexport diverzifikációjával tompíthatóak a volumenhordozó termékek világpiaci árának ingadozásából adódó kedvezőtlen gazdasági hatások, az exportbevétel pedig egyenletesebbé, kiszámíthatóbbá tehető a több lábon állásnak köszönhetően. Az exportra kerülő speciális termékek mennyiségének növekedésével párhuzamosan az azokat előállító termelők anyagi biztonsága, termelési kedve is növekedhet, ami kedvező hatással lehet a magyar mezőgazdaság fejlődésére.

A diverzifikációnak vannak azonban hátrányai is. Mivel változatos termékekről és kisebb volumenekről van szó, jelentősen megnövekszik az értékesítési folyamatba bevont szervezetek száma. A különböző termékcsoportok eltérő jellegéből adódóan az exporthoz különféle állat- és növény-egészségügyi igazolások kellenek, másféle értékesítési csatornákra van szükség, és a forgalom nyilvántartása is bonyolultabbá válik a sokszínűség és a kisebb volumenek miatt. A nehezebb áttekinthetőség következtében a speciális termékek termelésének és exportjának állami szabályozásának és a támogatási rendszernek az átalakítására is szükség lehet. Ezek a tényezők mind jelentős költségnövekedést okoznak, ezért felmerülhet a kérdés, hogy az agrárexport diverzifikációjával elérhető exportbevétel-növekedés arányban van-e a vele járó költségnövekedéssel.

A kérdés eldöntéséhez meg kell vizsgálni, hogy mely termékek tartoznak a diverzifikációnál számításba vehető körbe, ezek jelenleg milyen piaci pozíciókkal rendelkeznek, valamint milyen szerepet játszanak az agrárexportban. E cikk keretében a speciális termékek közül a gomba jelenlegi magyarországi piaci és termelési hátterét mutatom be.

\section{ANYAG ÉS MÓDSZER}

A gombatermesztésre vonatkozó információkat az adott termékhez kapcsolódó érdekképviseleti szervektől, terméktanácsoktól és a kapcsolódó hazai és nemzetközi irodalmi forrásokból gyüjtöttem. Munkámhoz felhasználtam a külföldi tanulmányútjaim során - Angliában és Írországban szerzett személyes tapasztalataimat és az ott gyüjtött adatokat is. $\mathrm{Az}$ összegyüjtött ismeretanyagot kiegészítettem néhány gombatermesztővel készített mélyinterjúval és saját kérdőíves felméréssel is. A kutatás során 25 , az ország különböző területein tevékenykedö, véletlenszerúen kiválasztott termelőnek juttattam el kérdőívet. A kérdések a gombatermesztés piaci jellemzőire és termelési 
hátterére vonatkoztak. Mindezek mellett jó képet kaptam a termelők véleményéről az ágazat problémáival kapcsolatosan. A kiküldött kérdöívekből összesen $20 \mathrm{db}$ érkezett vissza. Ezek között voltak hiányosan kitöltöttek is ( $2 \mathrm{db})$, azonban a megválaszolt kérdéseknél természetesen figyelembe vettem a bennük közölt válaszokat is. A válaszadók viszonylag kis száma miatt az eredmények nem tekinthetők szignifikánsnak, azonban jeleznek olyan tendenciákat, melyek jelzésértékűek lehetnek a szakemberek számára.

$\mathrm{Az}$ összegyüjtött adatokat a MS EXCEL 5.0 program segítségével dolgoztam fel. Munkám során a program által biztosított egyszerübb matematikai és statisztikai módszereket (százalékszámítás, számtani átlag számítás) alkalmaztam. A kapott eredményeket a könnyebb értelmezhetőség érdekében táblázatokba foglaltam és - ahol ennek szükségét láttam - az EXCEL-ben készített grafikonokat és diagramokat használtam a szemléltetésre

\section{A GOMBATERMESZTÉS SZEREPE A FOGLALKOZTATÁSBAN}

A gombatermesztés bevételt és munkalehetőséget kínálhat már a kisebb gazdaságokban is, emellett ideális kiegészítő tevékenység lehet a felesleges munkaerő kihasználására. A mérettől függően a gombatermesztés lehet elsődleges bevételi forrás (a megkérdezettek 70\%-ánál), de másodállásban vagy más mezőgazdasági tevékenységgel együtt is végezhető (a válaszadók 30\%-a esetében). Ez utóbbi esetben - kitűnő pénzáramlási mutatói miatt - igen jó jövedelem-kiegészítésül szolgál, mivel átlagosan a felmérésben szereplők összes jövedelmének 30-40\%át adja. Érdemes megemlíteni, hogy a gombatermesztők szinte mindegyike a nagyobb jövedelem reményében kezdte el tevékenységét, a hagyományok egyáltalán nem játszanak olyan fontos szerepet, mint pl. a nyúltenyésztés esetében. Az utóbbi években - elsősorban a nyugati országokban egyre többen foglalkoznak szabadidős tevékenységként, „hobbiból” a gombatermesztéssel. Magyarországon jelenleg 40 cég és több mint 1.500 termesztő dolgozik az ágazatban, mely így több mint 10 ezer ember megélhetését biztosítja. Kimondottan gombatermesztéssel 25-30 nagy, 300 közepes és mintegy 600-700 kistermelö foglalkozik (HajdúBihari Napló, 2000).

\section{A TERMELÉS VÁLTOZÁSAI RENDSZERVÁLTÁST KÖVETÖEN}

Az utóbbi évtizedben a gombatermesztés is jelentős változásokon ment keresztül, azonban a legtöbb mezőgazdasági ágazattól eltérően ez nem járt termelés-visszaeséssel. Éppen ellenkezőleg: a gombatermesztés dinamikusan növekedett, aminek eredményeképpen a megtermelt gomba mennyisége 1990-hez képest a hétszeresére (!) emelkedett (1. ábra).

A termelés évi átlagos (számtani) növekedési üteme 1990 és 2000 között 23\% volt, ami évenként
3.300 tonnás termelésbővülésnek felel meg (1. táblázat). Ez a növekedés 1999-2000-ben némileg lelassult, ami a III. fázisú komposzt bevezetésének köszönhető. (Az általam megkérdezettek 40\%-a már ilyen komposztot használt 2000-ben.) A gombatermesztők többsége ugyanis még nincs teljesen tisztába ennek a komposztnak a használatával, ami egyes termelőknél alacsonyabb terméssel, míg másoknál épp ellenkezőleg, túl magas hozammal járt, amire nem voltak kellöképpen felkészülve, így annak jelentős része veszendőbe ment.

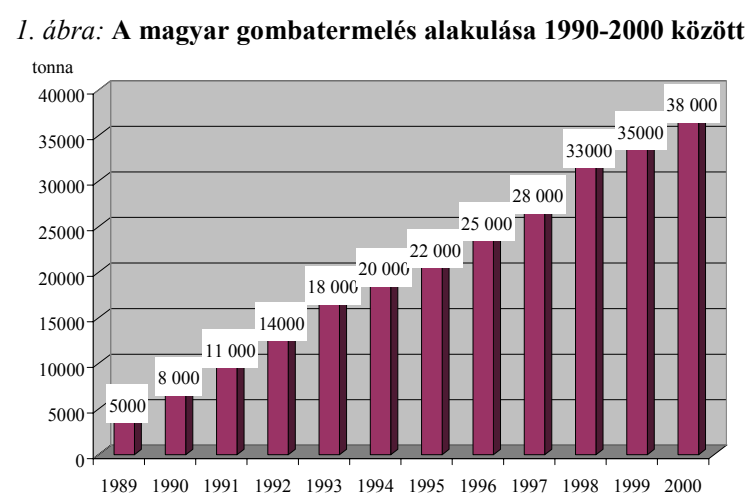

Forrás: Országos Zöldség Terméktanács (OZT)

Figure 1: Changes in Hungarian mushroom production levels between 1990-2000

1. táblázat

A gombatermelés változásai 1989 és 2000 között

\begin{tabular}{|l|r|r|r|}
\hline & Termelés(t)(1) & $\begin{array}{c}\text { Termelés- } \\
\text { növekedés az } \\
\text { elözó évhez } \\
\text { képest (t)(2) }\end{array}$ & $\begin{array}{c}\text { Termelés- } \\
\text { növekedés (az } \\
\text { elözó év \%- } \\
\text { ában)(3) }\end{array}$ \\
\hline $\mathbf{1 9 8 9}$ & 5.000 & - & - \\
\hline $\mathbf{1 9 9 0}$ & 8.000 & 3.000 & $60,0 \%$ \\
\hline $\mathbf{1 9 9 1}$ & 11.000 & 3.000 & $37,5 \%$ \\
\hline $\mathbf{1 9 9 2}$ & 14.000 & 3.000 & $27,3 \%$ \\
\hline $\mathbf{1 9 9 3}$ & 18.000 & 4.000 & $28,6 \%$ \\
\hline $\mathbf{1 9 9 4}$ & 20.000 & 2.000 & $11,1 \%$ \\
\hline $\mathbf{1 9 9 5}$ & 22.000 & 2.000 & $10,0 \%$ \\
\hline $\mathbf{1 9 9 6}$ & 25.000 & 3.000 & $13,6 \%$ \\
\hline $\mathbf{1 9 9 7}$ & 28.000 & 3.000 & $12,0 \%$ \\
\hline $\mathbf{1 9 9 8}$ & 33.000 & 5.000 & $17,9 \%$ \\
\hline $\mathbf{1 9 9 9}$ & 35.000 & 2.000 & $6,1 \%$ \\
\hline $\mathbf{2 0 0 0}$ & 38.000 & 3.000 & $8,6 \%$ \\
\hline
\end{tabular}

Forrás: OZT, ill. saját számítás

Table 1: Changes in Hungarian mushroom production between 1989 and 2000

production, $\mathrm{t}(1)$, yearly production changes, $\mathrm{t}(2)$, production changes as a percent of previous year(3)

A megtermelt gomba legnagyobb részét, mintegy $85-90 \%$-át a csiperkegomba teszi ki. A laskagomba 9-10\%-kal, míg a shii-take 1-2\%-kal részesedik az össztermésből. A felsorolt gombafajokon kívül még néhány gombafaj - pl. harmatgomba, gyapjas 
tintagomba, pecsétviasz gomba stb. - termesztésére van lehetőség, azonban ezek mennyisége nem éri el a kereskedelmi szintet. A csiperkefajták közül a fehér csiperke a legismertebb és a legnagyobb mennyiségben termesztett gomba, de a barna kalapos csiperkére is lenne kereslet belföldön és külföldön egyaránt.

A „Hungaricum”-nak számító laskagomba - úgy tünik - kiheverte az elmúlt évek termelési válságát, így várható, hogy a közeljövőben - az export növekedése mellett - a hazai piacokon is nagyobb szerephez jut. A shii-take - melyet a korábban ismertetett okok miatt sokan a XXI. század termesztett gombájának tartanak - termelése is folyamatosan növekszik, azonban az előző két gombafajhoz képest a termésmennyiség igen ingadozó és kiszámíthatatlan.

Összességében elmondható, hogy az alapanyagok tekintetében a magyar gombatermesztés igen jól áll, hiszen az igényeknek megfelelő mennyiségben és minőségben vagyunk képesek azt előállítani. A termelés növekedésének legnagyobb akadálya a termesztés területén tapasztalható technológiai lemaradás, mely jelentősen megnehezíti a hazai gombatermesztők helyzetét.

A termelésben leginkább elterjedt módszer ugyanis a zsákos termesztés, melynek az élőmunkaigénye igen magas, ezért a termesztők 25\%-ának van állandó alkalmazottja és a többi $75 \%$ is igénybe vesz alkalmanként külső segítséget. A kérdőíves felmérés alapján elmondható, hogy a gombatermesztés elsősorban pincékben $(55 \%)$ és átalakított épületekben $(20 \%)$ folyik. A pincei termesztésben nagy gondot okoz, hogy a nem klimatizált pincékben a nyári höség idején nem lehet biztonságosan termelni, ami jelentős jövedelem-kieséssel jár.

Ugyanez a probléma a felszíni épületekkel (volt istállókkal, mezőgazdasági épületekkel) is, amennyiben a klimatizálásuk nem megoldott. Ha azonban sikerül megoldani a hőszigetelést és a klíma szabályozását, alkalmassá tehetők gombatermesztés céljára. Ezeknek az épületeknek a pincékkel szembeni nagy előnyük az, hogy a gépesítésük és fertőtlenítésük könnyebben megoldható, mint a pincékben.

A gombatermesztés harmadik módja a speciális, kimondottan gombatermesztés céljából épített fóliasátrak és fóliaházak használata, melyekben a válaszadók 25\%-a folytatja tevékenységét. Az utóbbi időben megfigyelhető tendencia szerint ezek a klimatizált termesztőházak - legalábbis az üzletszerü gombatermesztésben - kezdik átvenni a pincék helyét (Rózsai és Nagy, 1997).

A gomba-ágazatra is - a mezőgazdaság egészéhez hasonlóan - jellemző a tőkehiány, ami igen nehézzé teszi (illetve sokszor ellehetetleníti) a beruházásokat. Mivel a gombasátrak és termesztőházak építése igen költséges, ezért a termelők állami segítségre szorulnak. Jó megoldás lenne, ha kedvezményes, hosszú lejáratú hiteleket vehetnének fel a termelők (Világgazdaság, 1999). A támogatásnak ez a formája Európa legnagyobb gombatermesztő országában, Hollandiában is elterjedt és sikeres. A befektetés megtérülne, mivel a gombát extraprofittal lehetne értékesíteni. Ha azonban nem történik meg a technológiaváltás, akkor könnyen elveszíthetjük kedvező piaci pozícióinkat. A fejlesztéshez nagy segítséget jelenthet az állami támogatás, mely a termesztők részére 2001-től rendelkezésre áll gombapincék korszerúsítésére, illetve gombasátrak létesítésére.

\section{A GOMBA ÉRTÉKESÍTÉSÉNEK ÉS EXPORTJÁNAK FÖBB JELLEMZÖI}

Magyarországon a gomba kereskedelme a mezőgazdaság más ágazatainak termékeitől eltérően, egyedi módon alakult ki. A megtermelt gomba jelentős részét (20-80\%-át) legtöbbször maguk a termesztők adják el a vevőknek, illetve a nagybani piacokon. Az utóbbi időben azonban a kiskereskedelem átalakulásának következtében - a nagy áruházláncok, szupermarketek elöretörése miatt (melyek a gombatermés 30-80\%-át veszik meg) egyre csökken a nagybani piaci értékesítés. Ezek a kereskedelmi láncok rendkívül jól szervezettek és ezt a szállítóiktól is megkövetelik. A termelőknek képeseknek kell lenniük arra, hogy az igényelt mennyiséget mindig azonos minőségben és pontossággal szállítani tudják. Ezeket a követelményeket a kistermelök az esetek többségében nem tudják teljesíteni, ezért nem véletlen, hogy hazánkban is egyre terjedőben van a gombakereskedelem jelentős gombatermesztő országokban - mint pl. Írország - elterjedt módja. Ez alapvetően egy ún. szatellit rendszeren alapszik, aminek lényege, hogy az egyéni termelők egy központi komposztgyártó céghez kapcsolódnak, mely ellátja öket a gombacsírákkal telített komposzttal. Ezek a cégek aztán összegyüjtik, osztályozzák, majd piacra viszik a megtermelt gombát, így - több forrásból intézve felvásárlásaikat - már ki tudják elégíteni a szupermarketek igényeit és feltételeit. A termelők így gombájuknak biztos piacot találnak, és - nem mellesleg - a szerződés keretében a komposztot is olcsóbban kapják.

A magyar gombatermelés növekedésével párhuzamosan az exportra kerülö gomba mennyisége is folyamatosan növekedett. 1999-ben több mint 16 ezer tonna friss gombát (2. ábra) és 11 ezer tonna gombacsírát exportáltunk. Ez azt jelenti, hogy az exportra került mennyiség 1991-óta az ötszörösére növekedett. Érdemes megemlíteni, hogy a laskagomba kivitelünk 1997 és 1999 között megduplázódott. Az ágazat exportorientáltságát mutatja, hogy a Magyarországon megtermelt gomba egyre növekvő hányada - 1999-ben már 46\%-a külföldi piacon talál vevőkre (ez az arány 1995-ben még csak $30 \%$ volt).

Az export volumenének bővülésével egyidejüleg évről évre növekedett a gombából származó exportbevételünk is, s az 1999-es évben elérte a 30 millió dollárt (3. ábra). A gombakivitel legnagyobb részét a termesztett gomba képezi, aminek 85-90\%-át a csiperke adja. A maradékon a laskagomba (9-10\%) és az egyéb gombafélék (1-2\%) osztoznak. 
Konzervgombaként - aminek éves mennyisége 160790 tonna között változik - szinte kizárólag csiperkét értékesítünk.

\section{2. ábra: A magyar friss gombaexport mennyiségének alakulása} 1990-1999 között

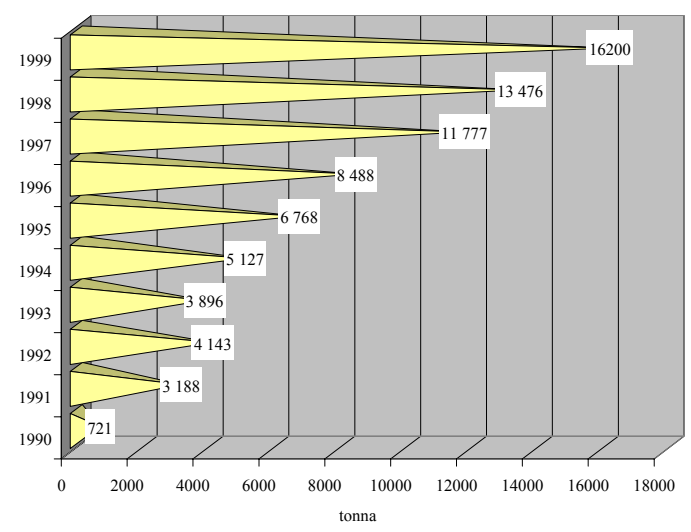

Forrás: OZT

Figure 2: Hungarian mushroom export between 1990-1999 in tons

3. ábra: A magyar friss gombaexport értékének alakulása 1990-1999 között

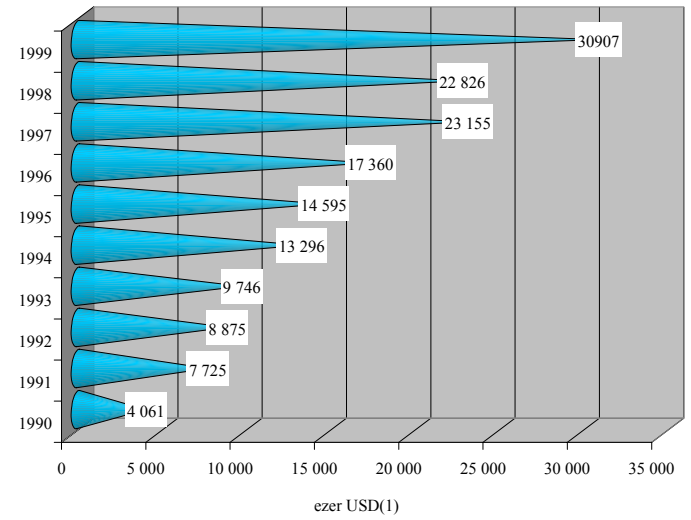

Forrás: OZT

Figure 3: The changes in mushroom exports (1990-1999) thousand USD(1)

A friss gomba legfőbb piaca hagyományosan az Európai Unió, azon belül is Ausztria és Németország (4. ábra). A gombaexport a földrajzi relációt tekintve igen koncentrált, mivel ebbe a két országba kerül az összes kiszállított gombamennyiség 84\%-a és innen kapjuk a gombaexportból származó bevételeink közel $90 \%$-át. Ausztria a csiperkegomba legfóbb piaca, míg Németország - a jelentős csiperkevásárlás mellett - a magyar laskagomba legfontosabb importőre. A harmadik helyen álló Olaszországba szinte kizárólag csiperkét exportálunk, amelynek értéke 1999-ben 1,2 millió dollár volt. Románia és Horvátország éves szinten mintegy 300-300 ezer dollárral járul hozzá az exportbevételekhez. A konzervgomba kivitelünk a környező országokba (Csehország, BoszniaHercegovina stb.) irányul, mivel a magas védővám miatt nem versenyképes az EU piacain (Magyar Agrárkamara, 1999).

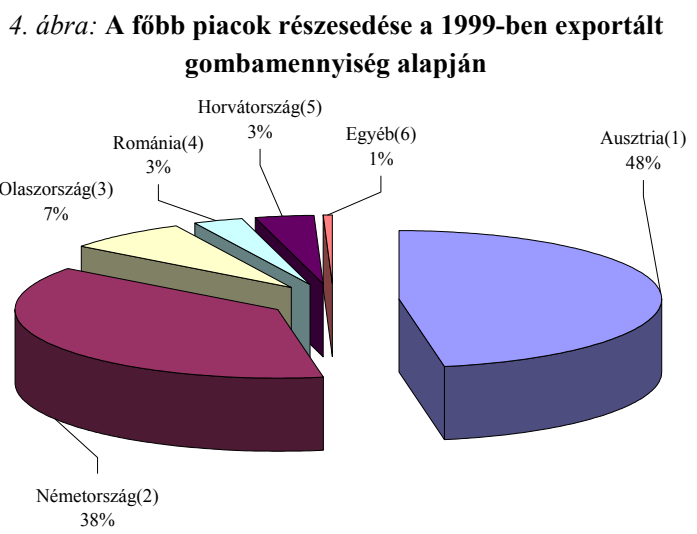

Forrás: saját számítás

Figure 4: The main export markets for Hungarian mushroom in 1999

Austria(1), Germany(2), Italy(3), Romania(4), Croatia(5), Other countries(6)

Mint láthatjuk, a magyar gombatermékek több mint 90\%-a az Európai Unióban talál vevőre. Ez a nagyfokú területi koncentráció és - ezzel együtt - az ottani értékesítési ár változása az oka annak, hogy az exportárbevétel nem növekedett ugyanolyan mértékben, mint a kiszállított mennyiség. Az értékesítési árak az EU-ban ugyanis az utóbbi években folyamatosan csökkentek (2. táblázat).

A friss gomba átlag exportárának alakulása 1996-1999 között (USD/kg)

\begin{tabular}{|r|r|r|}
\hline & \multicolumn{1}{|c|}{ Csiperke(1) } & Laskagomba(2) \\
\hline $\mathbf{1 9 9 6}$ & 1,94 & 2,67 \\
\hline $\mathbf{1 9 9 7}$ & 1,90 & 2,76 \\
\hline $\mathbf{1 9 9 8}$ & 1,63 & 2,40 \\
\hline $\mathbf{1 9 9 9}$ & 1,52 & 2,03 \\
\hline
\end{tabular}

Forrás: G14, ill. saját számítás

Table 2: The export prices of fresh mushroom between 19961999 (USD/kg)

Champignon(1), Oyster-mushroom(2)

Az Európai Unió piacain a magyar gombának legnagyobb konkurenciát Hollandia, a volt szocialista országok közül pedig Lengyelország jelenti. Azonban míg Hollandiában a gombatermesztésre a mezőgazdasági stratégiában jelentős figyelmet fordítanak, nálunk még a kertészeti ágazatok között sem kap megfelelö támogatottságot.

Magyarország számára irreális cél lenne a holland piaci részesedés csökkentése, mivel sem árban, sem pedig mennyiségben nem tudjuk felvenni velük a versenyt. A korábban már említett hátrány (a pincei termesztés nagy aránya) viszont a német piacon előnnyé fordítható, mivel a pincében termelt gomba iránt - annak kedvező szárazanyag-tartalma és jó 
eltarthatósága miatt - folyamatos kereslet van (Nagy, 1997). Ezt a különbözőséget kihasználva ebben a piaci szegmensben vezető szerepet tölthetnénk be (mivel a hollandok többnyire felszíni termesztést folytatnak). További lehetőségeket kínál még a laskagomba és a shii-take gomba is, melyekből az EU termelése igen alacsony.

A magyar gomba piacra jutását nehezíti, hogy a gombára vámkontingensek vannak érvényben, melyek az EU kibővülésével sem változtak. Ez Ausztria EU csatlakozása miatt igen érzékenyen érintette a magyar kereskedőket, mivel a kedvezményes, 3\%-os vám helyett a kontingens kihasználása után kénytelenek voltak jóval magasabb, 14,9\%-os vám mellett szállítani (Rózsai és Nagy, 1997). Ez a magas vám rontotta az alkupozíciókat és csak alacsonyabb bevételek elérését tette lehetővé.

A csiperkegomba esetében Magyarország 1999. július 1. és 2000. június 30 . között 4.200 tonna kedvezményes kvótával rendelkezett (Csendes és Maczák, 1999). Ez a kedvezményes kvóta a 2000 közepén történt megállapodást követően 8.000 tonnára emelkedett (mely vámkontingens évente 800 tonnával növekszik majd). Eddig a mennyiségig 2,8\%-os kedvezményes vám érvényes, e felett viszont továbbra is marad a $12,8 \%$-os vám (Koronczy, 2001). Laskagomba esetében nem rendelkezünk ilyen kedvezményes kvótával. A gombakonzerv esetében a vám igen magas, mértéke $19,2 \%+231$ Euro/100 kg gomba. Ez a vámteher a vételár közel kétszerese.

\section{A GOMBATERMESZTÉS KÖLTSÉG- ÉS JÖVEDELEMVISZONYAI}

A gombatermesztők túlnyomó része vásárolt komposzton illetve alapanyagon termel, melyet többnyire (kutatásaim alapján 90-100\%-ban) állandó, szerződéses partnerektől szereznek be. A jó minőségű komposzt a sikeres termeléshez elengedhetetlen fontosságú, nem véletlen tehát, hogy a becsírázott komposzt beszerzési ára teszi ki a költségek legnagyobb részét, több mint 50\%-át. A gombatermesztés alapanyagai ma már az ország minden területén beszerezhetök megfizethetö áron.

A gombatermesztés - a kertészeti ágazatok többségéhez hasonlóan - élőmunka-igényes ágazat. Az elvégzendő munkák két fö részre oszthatók, melyek eltérő képzettségű munkaerőt igényelnek. Az egyik rész a fizikai munka, mely a komposzt kezeléséhez (behordás, gyürés, takarás, borzolás, kihordás) szükséges. Ezt egy átlagos képességü mezőgazdasági munkás el tudja végezni. A munkák másik része a szedéshez kapcsolódik. A jól képzett és hozzáértő szedők (többnyire nők) nagymértékben növelhetik a megtermelt gomba mennyiségét és minőségét is. A gomba ugyanis több hullámban terem, így a szakszerütlen szedés tönkreteheti a következő termést. Az is nagyon fontos, hogy a gomba megfelelö méretben és időben legyen leszedve (se túl korán, se túl későn). Ezért nem véletlen, hogy a gombatermesztés költségei között igen jelentős részt tesz ki az élőmunka költsége (3. táblázat). Mivel Magyarországon az élőmunka még viszonylag olcsónak tekinthető, ebből a szempontból versenyelőnyben vagyunk az Európai Unió gombatermesztőivel szemben. Írországban - ahol az EU-s csatlakozást követően a gombatermesztés igen dinamikus fejlődésnek indult - például a munka költsége a magyarországinál sokkal nagyobb részt (40\%) képvisel a termelési költségeken belül. Igaz, hogy a kedvezőbb piaci pozícióik miatt ezt a hátrányt a magasabb árral kompenzálni tudják.

A táblázat csak a gombatermesztés közvetlen költségeit tartalmazza, így nem szerepel benne a gombatermesztő saját munkadíja, a gomba csomagolásának, hűtésének és szállításának költsége, illetve a komposzt mozgatásához használt gépek költsége (ha vannak ilyenek), illetve az amortizáció. Ezek még kb. 10-15\%-kal növelik meg az összköltséget. A komposzt beszerzési adatok II. fázisú komposztra vonatkoznak.

A gombatermesztés költségszerkezete Magyarországon és Î́rországban 1999-ben

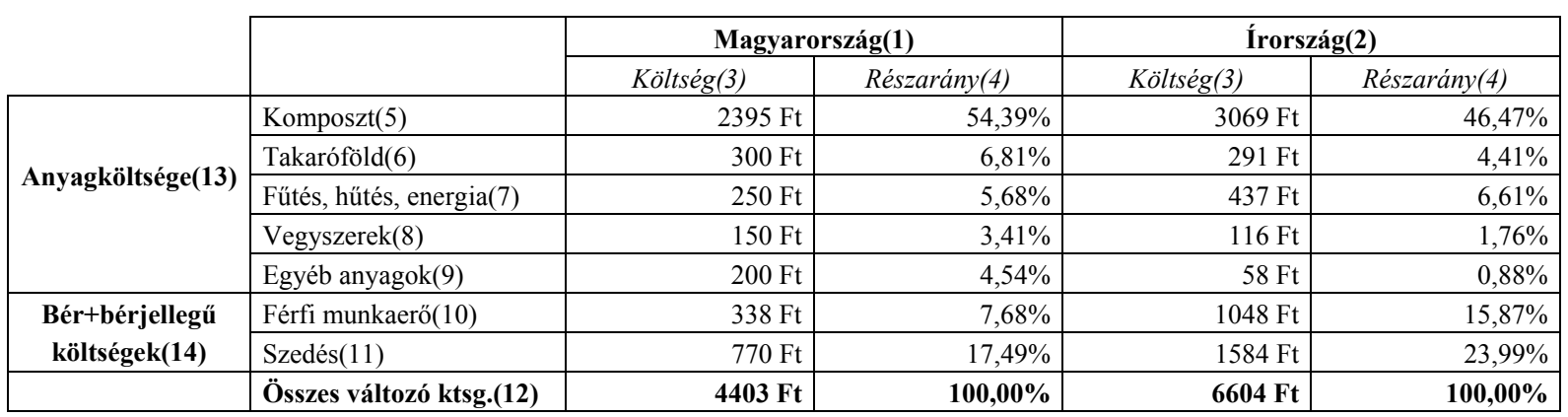

Forrás: OZT és TEAGASC

Table 3: The cost-structure of mushroom production in Hungary and Ireland (for $100 \mathrm{~kg}$ spawned compost, at a yield of $22 \mathrm{~kg} / 100 \mathrm{~kg}$ compost)

Hungary(1), Ireland(2), cost(3), share(4), compost(5), casing(6), heat, power, light(7), chemicals(8), miscellaneous(9), hired labour(10), picking(11), total variable costs(12), material costs(13), labour costs(14) 
$\mathrm{Az}$ ír tapasztalatok azt mutatják, hogy a gombatermesztés éves jövedelmezősége igen érzékeny az adott mennyiségü komposzton megtermelt gomba mennyiségének változására (Cawley és mtsai, 1995). Így például egy három egységes (három sátorból álló) gombatermesztő-telep jövedelme évi 5 termés esetén (20 kg gomba/ $100 \mathrm{~kg}$ komposztnál) meghaladja a 11 ezer ír fontot ${ }^{1}$. (Ez kb. 3,6 millió Ft-nak felel meg.) A termés $1 \mathrm{~kg}$-os növekedése esetén a jövedelem 13.590 ír font $(4,5$ millió $\mathrm{Ft}$ ), míg $1 \mathrm{~kg}$-os csökkenésekor 8.595 ír font (2,8 millió Ft) lenne. Ez azt mutatja, hogy a termelö és a szedők szaktudása és gondossága jelentősen befolyásolhatja az elérhető jövedelmeket.

Természetesen a fenti megállapítások Magyarországon is igazak, amint azt a 4. táblázat mutatja. A táblázatban szereplő értékek kiszámolásánál figyelembe vettem a magasabb termések nagyobb élőmunka (elsősorban szedés) igényét - ezzel magasabb költségeit - is. Látható, hogy az átlagosnak nevezhető $24 \mathrm{~kg}$-os termelési szinten és 240 Ft-os piaci áron már 29\%-os jövedelmezőség érhető el. Nem szabad azonban megfeledkezni róla, hogy ezt a (bruttó) jövedelmet olyan költségekre vonatkoztattam, melyek nem tartalmazzák pl. a vállalkozó saját bérét. Viszont ennek figyelembevételével is elmondható, hogy a gombatermesztés átlagos színvonalon és a kialakult piaci árakon a mezőgazdasági ágazatok többségénél magasabb jövedelmek elérését teszi lehetővé. Amennyiben a termelö képes magasabb hozamok elérésére (30-34 kg/100 kg komposzt, ami az új, III. fázisú komposzttal már könnyen teljesíthető), akkor igen jelentős bevételekre tehet szert. Ezt jól mutatja a felmérésben résztvevő néhány termesztő példája, akik ezzel a komposzttal termelve 57-132\%-os (!) költségarányos bruttó jövedelmekről számoltak be.

4. táblázat

A gombatermesztés jövedelmezősége 1999-ben Magyarországon különböző termelési szinteken és piaci árakon (100 kg komposztra vonatkoztatva)

\begin{tabular}{|c|c|c|c|c|c|c|c|c|c|c|c|}
\hline & \multicolumn{10}{|c|}{ Termés (kg)(1) } \\
\hline & & 16 & 18 & 20 & 22 & 24 & 26 & 28 & 30 & 32 & 34 \\
\hline \multirow{7}{*}{ 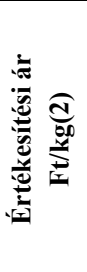 } & 180 & -1313 & -1023 & -733 & -443 & -153 & 137 & 427 & 717 & 1007 & 1297 \\
\hline & 200 & -993 & -663 & -333 & -3 & 327 & 657 & 987 & 1317 & 1647 & 1977 \\
\hline & 220 & -673 & -303 & 67 & 437 & 807 & 1177 & 1547 & 1917 & 2287 & 2657 \\
\hline & 240 & -353 & 57 & 467 & 877 & 1287 & 1697 & 2107 & 2517 & 2927 & 3337 \\
\hline & 260 & -33 & 417 & 867 & 1317 & 1767 & 2217 & 2667 & 3117 & 3567 & 4017 \\
\hline & 280 & 287 & 777 & 1267 & 1757 & 2247 & 2737 & 3227 & 3717 & 4207 & 4697 \\
\hline & 300 & 607 & 1137 & 1667 & 2197 & 2727 & 3257 & 3787 & 4317 & 4847 & 5377 \\
\hline
\end{tabular}

\begin{tabular}{|c|c|c|c|c|c|c|c|c|c|c|c|}
\hline & \multicolumn{10}{|c|}{ Termés (kg)(1) } \\
\hline & & 16 & 18 & 20 & 22 & 24 & 26 & 28 & 30 & 32 & 34 \\
\hline \multirow{7}{*}{ 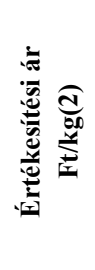 } & 180 & $-31 \%$ & $-24 \%$ & $-17 \%$ & $-10 \%$ & $-3 \%$ & $3 \%$ & $9 \%$ & $15 \%$ & $21 \%$ & $27 \%$ \\
\hline & 200 & $-24 \%$ & $-16 \%$ & $-8 \%$ & $0 \%$ & $7 \%$ & $14 \%$ & $21 \%$ & $28 \%$ & $35 \%$ & $41 \%$ \\
\hline & 220 & $-16 \%$ & $-7 \%$ & $2 \%$ & $10 \%$ & $18 \%$ & $26 \%$ & $34 \%$ & $41 \%$ & $48 \%$ & $55 \%$ \\
\hline & 240 & $-8 \%$ & $1 \%$ & $11 \%$ & $20 \%$ & $29 \%$ & $37 \%$ & $46 \%$ & $54 \%$ & $62 \%$ & $69 \%$ \\
\hline & 260 & $-1 \%$ & $10 \%$ & $20 \%$ & $30 \%$ & $40 \%$ & $49 \%$ & $58 \%$ & $67 \%$ & $75 \%$ & $83 \%$ \\
\hline & 280 & $7 \%$ & $18 \%$ & $29 \%$ & $40 \%$ & $50 \%$ & $60 \%$ & $70 \%$ & $79 \%$ & $89 \%$ & $97 \%$ \\
\hline & 300 & $14 \%$ & $27 \%$ & $38 \%$ & $50 \%$ & $61 \%$ & $72 \%$ & $82 \%$ & $92 \%$ & $102 \%$ & $111 \%$ \\
\hline
\end{tabular}

Forrás: saját számítások

Table 4: The profitability of mushroom production in Hungary at different production and price levels (for $100 \mathrm{~kg}$ compost) production, $\mathrm{kg}(1)$, sale price, $\mathrm{Ft} / \mathrm{kg}(2)$

\section{A VERSENYKÉPESSÉG JAVÍTÁSÁNAK LEHETÖSÉGEI A GOMBATERMESZTÉSBEN}

A gombatermesztés további fejlődését segíthetné elö a magyar belföldi gombafogyasztás növelése, ugyanis amíg az 1 före jutó termelés esetében (3-3,5 $\mathrm{kg} /$ fö/év) felette vagyunk az európai átlagnak $(2,4$ $\mathrm{kg} /$ fö/év), addig a fogyasztás tekintetében elmaradunk az európai átlagtól (2,5-3 kg/fö/év). Ez az elmaradás annak ellenére megmaradt, hogy az utóbbi években a gombafogyasztás nálunk is növekedett, s mára elérte az évi 1,7-2,1 kg-os szintet. Ez az emelkedés részben a nagy áruházláncok elterjedésének köszönhető, mivel ezek kínálatában a gomba állandó jelleggel szerepel. A fogyasztás növelésében emellett az OZT Gomba Tagozata is fontos szerepet játszik a kóstoltatási akciók megszervezésével és a tájékoztató kiadványok megjelentetésével. Amennyiben sikerülne a hazai gombafogyasztást az európai szintre emelni, az a gombatermesztőknek évi 8-10 ezer tonnás piacbővülést jelentene.

A fogyasztói igényeket - ez vonatkozik a kül- és belpiacokra egyaránt - azonban csak akkor lehet kielégíteni, ha a termelők alkalmazkodnak azokhoz. Így például a jövőben várhatóan csökkeni fog az ömlesztett, 6 kg-os ládákban forgalmazott gombák részaránya a különböző mennyiségekben fóliával 
borított dobozos gombával szemben. Ez a gombatermesztőktől (a nagytermelőktől és a családi gazdaságoktól egyaránt) megköveteli a csomagolástechnika és a hütőkapacitás fejlesztését. A hütés, a megfelelő csomagolás és a hütőkocsis szállítás azonban olyan összegü beruházásokat igényel, melyet a kisebb termesztők egyedül nem képesek megvalósítani, mivel számukra ez nem lenne rentábilis. A probléma megoldását a termelök összefogása, termelői szövetkezések létrehozása jelenthetné. Ezek a termelő és értékesítő szövetkezetek (TÉSZ) sokat javíthatnának a termesztők piaci pozícióin és a piacra vitt áru minőségén is. Ezt a ,javulást” a piac árnövekedéssel honorálná, ami kedvező irányba befolyásolná a gombatermesztés jövedelmezőségét és a jövedelemtermelés biztonságát, így elősegítené az ágazat jövőbeni fejlődését is. A TÉSZ-ek létrehozására azért is szükség van, mert az Európai Unió csak ezeken a szervezeteken keresztül hajlandó támogatni a zöldség-gyümölcs ágazatot (Magyar Agrárkamara, 1999). A megkérdezett gombatermesztők mindegyike hallott már a TÉSZekről és jelentős részük (90\%-uk) szívesen tagja is lenne ilyen szervezetnek. Jelenleg azonban csak $15 \%$-uk vesz részt valamilyen termelési integrációban.

A gombatermesztés további növekedésének lehet az alapja a III. fázisú komposzt szélesebb körü elterjedése, mely a két héttel rövidebb termelési periódus és a nagyobb termésátlagok miatt az évi gombatermelésre pozitívan hat. (Érdemes itt megemlíteni, hogy Hollandiában már terjed a IV. fázisú komposzt is - mely már gombakezdeményeket is tartalmaz -, s ezáltal még rövidebb idő alatt termőre fordul.) A III. fázisú komposzt alkalmazásához azonban megfelelő szakismeretek szükségesek, amit - megfelelő szaktanácsadás hiányában - a termesztők csak nehezen tudnak megszerezni. Ezért a szaktanácsadói rendszer kiépítése és a szakemberképzés fejlesztése a gombaágazatban is elengedhetetlen fontosságú. Ez utóbbira már csak a múlt miatt is szükség van, hiszen a gombakutatás területén a magyar szakemberek világszerte elismertek. Az újabb gombák mesterséges termelésnek kidolgozása és azok termelésbe vonása jelentős versenyelőnyhöz juttatná a magyar gombatermesztést. E téren ma is folynak kutatások, így például Keszthelyen, a Veszprémi Egyetem Georgikon Mezőgazdaságtudományi Karán a szarvasgomba mesterséges termesztésének lehetőségeit vizsgálják. Amennyiben sikerül megoldani, ennek az igen keresett és drága gomba révén nagy jövedelmeket lehetne elérni. Addig is azonban bővíteni kell azoknak a gombáknak a termelését, melyekre kidolgozott eljárás van, s a csiperke mellett a választék bővítésére (laskagomba, téli fülöke, harmatgomba, shiitake stb.) vagy gyógyászati célokra (shiitake és egyéb ázsiai gombák) szolgálhatnak.

A gomba feldolgozása szintén a jövedelmezőség javulását szolgálhatná (a hozzáadott érték növelésével és az értékesítés biztonságának fokozásával), azonban a jelenlegi piaci viszonyok mellet még a belföldi piacon sem versenyképes az igen olcsó kínai importkonzervekkel. Itt kitörési pont lehet a minőségi gombakonzerv elöállítása választékbővítési célból. Ilyenek például a külföldön is keresett paradicsomos gomba vagy a gombasaláta. További lehetőséget nyújt a szárított gombatermékek (gombaszeletek, gombapor) előállítása.

\section{KÖVETKEZTETÉSEK}

Magyarország nettó agrárexportőri pozícióját csak akkor lehet fenntartani, ha megfelelö módon sikerül reagálni a világgazdaság változásaira. Ez azt jelenti, hogy a termelési (és a termék-) struktúrát a piaci igényekhez igazodva kell alakítani. Ebben az átalakuló struktúrákban a komparatív előnyeinket jól kihasználó alternatív mezőgazdasági ágazatok speciális termékei (mint például a gomba) is fontos szerepet játszhatnak, mivel a kistermelés keretei között is gazdaságosan állíthatók elö, kereskedelmük korlátozásokkal nem vagy csak kevésbé sújtott, piacuk pedig sok esetben szinte korlátlan. Az agrárexport diverzifikációjával tompíthatóak a volumenhordozó termékek világpiaci árának ingadozásából adódó kedvezőtlen gazdasági hatások, az exportbevétel pedig egyenletesebbé, kiszámíthatóbbá tehető a több lábon állásnak köszönhetően. Az exportra kerülő speciális termékek mennyiségének növekedésével párhuzamosan az azokat előállító termelők anyagi biztonsága, termelési kedve is növekedhet, ami kedvező hatással lehet a magyar mezőgazdaság fejlődésére.

A gombatermesztés jelentős hagyományokkal rendelkezik Magyarországon, ezért a termelési struktúra átalakításánál mindenképpen figyelmet érdemel. Ezt az is indokolja, hogy igen nagymértékben exportorientált ágazatról van szó, hiszen a megtermelt gomba $46 \%$-a külföldön talál vevőre. Mellette szól az a tény is, hogy a gombából az Európai Unió behozatalra szorul, így termelésükre semmiféle korlátozás nem vonatkozik, ellenben a csatlakozásunk után jelentős támogatásokat kaphatunk a gombaágazat fejlesztéséhez.

Szintén nagy elönye a vizsgált ágazatnak, hogy élőmunka-igénye viszonylag magas, így hozzájárulhat a vidéki lakosság foglalkoztatásának növeléséhez. Mindezek mellett kiegészítő tevékenységként is folytatható, ezért a mezőgazdasági termelők más, hagyományos termékekből származó jövedelmeit is jól kiegészítheti.

Ahhoz azonban, hogy a gombatermesztés tovább fejlődjön számos problémára kell megoldást találni. Az egyik ilyen gond - a mezőgazdaság egészéhez hasonlóan - a tőkehiány, ami a szükséges beruházások elmaradásához vezet és lehetetlenné teszi a fejlesztéseket. Szükség lenne a technológiaváltásra (gombasátrak és termesztőházak építésére), amihez a termelők nem rendelkeznek elegendő forrással. Véleményem szerint jó megoldás lenne a jelenleginél kedvezőbb feltételü hitelrendszer kialakítása. 
A fejlődés további fontos meghatározója a termelők szakmai ismerete. Megállapítható, hogy többségük megfelelő szakmai tapasztalatokkal rendelkezik, azonban a korszerü marketing- és piaci ismeretek terén hiányosságok tapasztalhatók. Az ismeretek bővitése érdekében célszerünek tartom egy olyan szaktanácsadói rendszer kiépítését, mely - a szakmai ismereteken túl - ezekre a kérdésekre is nagyobb hangsúlyt fektet.

Szintén jelentősen befolyásolhatja az ágazat sikerességét a megfelelö minőségü tenyészalapanyagok megléte. A gombatermesztés esetében a III. fázisú komposzt nemrég került bevezetésre, és ezért még sok minőségi probléma merült fel ezzel kapcsolatban. A komposztgyártók igéretei alapján azonban várhatóan ezek a gondok megoldódnak, és így megnyílik az út a csiperketermesztés további fejlödése előtt. A laskatermesztés esetében is vannak hasonló nehézségek, aminek fö oka a törzstenyészetek elöregedése.

Nem elég a termékeket elöállítani, azokat el is kell tudni adni. Az értékesítés alapvetően befolyásolja az ágazatok jövedelmezőségét, ezért a termelők alapvető érdeke a kiszolgáltatottság és a bizonytalanság csökkentése. Ehhez nagy segítséget nyújtana a termelők összefogása, azaz például a TÉSZ-ek létrehozása. A TÉSZ-ek létrehozása azért is időszerủ lenne, mert az EU csatlakozást követően a támogatásokat csak az ilyen szervezeteken keresztül lehet megpályázni.

Összefoglalásként elmondható, hogy a gombatermesztés a magyar mezögazdaság perspektivikus ágazata, mely - ha a szükséges fejlesztéseket végrehajtják - az EU csatlakozást követően is jelentős bevételekhez juttathatja az országot és magas jövedelmekhez a termelöket.

\section{IRODALOM}

Cawley M.-Gillmor D. A.-Leavy A.-McDonagh P. (1995): Farm diversification. TEAGASC, Dublin

Csendes J.-Maczák B. (1999): A hazai gombaágazat helyzete és jövője. Magyar Gomba, 3. 13. 9.

Koronczy I-né (2001): A lengyel vámmentesség. Magyar Gombahíradó, IX. 29. 5.

Nagy A. (1997): A magyar gombaágazat fejlődési üteme, ágazati stratégiaalkotás Swot analízis alapján. „Vállalati környezet és alkalmazkodás az élelmiszertermelésben”, Tudományos Konferencia Kiadvány III., Gödöllő, október 9-10., 41-45.

Rózsai A.-Nagy A. (1997): A magyar gomba bemutatkozik.
Élelmiszer Marketing, március 2. 1-6.

Hajdú-Bihari Napló (2000): Dinamikusan fejlödik a gombatermesztés. május 11.

Magyar Agrárkamara (1999): A zöldség-, a gyümölcs- és a borágazat EU-szabályozása: A harmonizáció lehetséges következményei. Agrárium, 9. 8. I-VI.

Országos Zöldség Terméktanács (1999): A zöldség és gyümölcs ágazat helyzete Magyarországon. OZT-AMC, Budapest

TEAGASC (2000): www.teagasc.ie

Világgazdaság (H., É.) (1999): Kedvezményes hitelre várnak a termelök. május 7. 